\title{
PEKANBARU CITY LIVESTOCK MARKETING WITH ANDROID-BASED APPLICATIONS
}

\author{
Yuvi Darmayunata ${ }^{*}$, Latifa Siswati ${ }^{2}$, Anto Aryanto $^{3}$ \\ Universitas Lancang Kuning, Indonesia ${ }^{123}$ \\ yuvidarmayunata@unilak.ac.id ${ }^{1 *}$, latifasiswati@unilak.ac.id ${ }^{2}$, antoariyanto@unilak.ac.id ${ }^{3}$
}

Received : 16 November 2021, Revised: 31 December 2021, Accepted : 31 December 2021

*Coresponding Author

\begin{abstract}
This research was conducted to provide solutions to cattle breeders in Pekanbaru City, especially in Rumbai District. Cattle breeders always have difficulty selling cows due to middlemen and coupled with the pandemic period due to the Covid 19 virus, thus making cattle sales decline every year. In increasing the sale of cattle during this pandemic is to use technology as a marketing solution. The technology used in the research is android based. With an Android base, consumers and producers will be integrated with each other so that the buying and selling process becomes easier. The purpose of this study is to help cattle sellers in marketing cattle so that the buying and selling process becomes easy. The method used is Unified Modeling Language (UML) in designing this system. The results show the success of designing applications for cattle sellers, applications can help farmers market their cattle, information about cattle prices to be compared in livestock groups can be seen so as to minimize fraud because buyers can directly see the price of the cattle.
\end{abstract}

Keywords: Android, Cattle Marketing, Covid 19 Pandemic.

\section{Introduction}

Along with the development of the digital era, internet access is increasingly accessible to the public. According to data released by the Association of Indonesian Internet Service Providers, internet users have continued to grow since the 18th century. In 1998 internet users in Indonesia were only 0.5 million people and increased to 132.7 million users in 2016. Internet users who continue to grow increasingly increase the frequency of internet access (Aprilia, et. al., 2018). The increasing population and changes in consumption patterns and people's tastes have caused the national consumption of beef to tend to increase. So far, the demand for beef in Indonesia is met from three sources, namely: local cattle, imported cattle, and imported meat. The population of cattle in Pekanbaru City is 4,555 heads (Pekanbaru Agriculture and Fisheries Statistics, 2019). So far, the marketing of cattle in Pekanbaru is dominated by middlemen. Farmers only raise cattle without thinking about marketing. The existence of intermediary traders in terms of breeders is very helpful when marketing their livestock and makes it easier for farmers to get cash when farmers need it(Rohmawati \& Ramadhani, 2020; Saravanan \& Saraniya, 2018).

With technology the problems that when marketing cattle will be a solution to the problems above. The technology applied is in the form of an information system that is placed on the android platform(Afandi, et. al., 2021). Making this application is intended so that consumers and sellers of cattle can make buying and selling transactions. The system is equipped with a selection of cash or non-cash payment methods (transfers) that are tailored to the wishes of the buyers(Subagyo \& Ardiansyah, 2020). So that at the time of payment transactions between buyers and sellers will be easier(Gupta, et. al., 2018). As for the formulation of the problem in this study, namely:

1. How to make an android application that can market the cows.

2. How about the android application will make it easier for cattle farmers to market their livestock. follows:

Based on the formulation of the existing problems, the objectives of this study are as

1. Helping consumers in purchasing cows

2. Increase the income of cattle sellers 


\section{Literature Review}

Kotler says that there are five factors that cause why marketing is important including: 1) the number of products sold decreases, 2) the growth in company appearance also decreases, 3) the changes that consumers want, 4) the competition is getting sharper., 5) too much expenses for the sale(Kango, et. al., 2020). Lole, et. al.,(2021) stated that at the inter-island merchant level, marketing costs are quite high, this is because the marketing chain is quite long. In other words, more and more marketing agencies are involved in transferring beef cattle products from farmers to farmers. Marketing channels can be said as channels that are used either directly or indirectly to facilitate the transfer of a product that moves from the producer to the consumer(Printezis \& Grebitus, 2018; Karray, et. al., 2021). The marketing system for agricultural products, including beef cattle with a small or subsistence scale, is monopolistic and exploitative(Ostaev, et. al., 2019; Sharma \& Burark, 2019). Hao, et. al., (2018) says that marketing channels are channels that are used either directly or indirectly to facilitate the selection of a product that moves from the producer to the consumer. Inefficient/relatively long marketing channels cause losses for both farmers and consumers, because consumers are burdened with heavy marketing costs to pay high prices. Meanwhile, for farmers, the income will be lower because the selling price received is much lower. The amount of the trading margin is determined by the size of the costs incurred and the risk borne by the trading system(Zhang, et. al., 2020). The number of feeder cattle imports and beef imports needs to be controlled in such a way that the price of beef cattle at the farmer level remains attractive. With a fairly good price for live cattle, farmers will continue to be passionate about running a beef cattle business, both breeding/breeding businesses to produce cows (cow-calf) and fattening to produce meat (fattening). Thus, the hope of achieving selfsufficiency in beef will be realized. Recently, controlling imports of feeder cattle and beef has an impact on increasing the price of cattle at the producer level. The availability of an adequate animal market in terms of quantity and affordability by farmers, helps them a lot in marketing the cattle they produce. Farmers generally market their cattle directly to available animal markets, only about 11.3 percent are still selling their cows through inter-island traders and inter-island traders, and even then more because they need urgent money and other emergencies(Kitano, et. al., 2022). At least this fact has helped farmers a lot in getting a decent price level and shortening the trade chain from farmers to final consumers. Rasda, et. al., (2021) stated that the distribution pattern of cattle in Eco-Friendly Farmers' Groups in Barru Regency in general is still long and involves many market players, resulting in a higher burden of marketing costs that become the burden of consumers. Subagja (2005) explains that in traditional marketing distribution patterns long and disorganized will involve many market participants. The marketing channels are complicated and long, leading to an increase in marketing margins, which is an average of more than $50 \%$ of the price paid by consumers, resulting in low marketing efficiency. Marketing strategy is one of the beginnings in order to introduce products to consumers and this will be very important because it will relate to the benefits that will be obtained by the company. Marketing strategies will be optimally useful if they are supported by structured planning both internally and externally. There are too many consumers and diverse purchasing requirements, so instead of competing in all segments, companies need to identify market segments that can be served most effectively, namely by conducting segmentation research. Philip Kotler, et. al., (2021) explains that segmentation is an integral part of targeting and positioning. Kotler abbreviated this relationship as STP (Segmentation, Targeting, and Positioning). This process is part of the activity of creating and delivering value to consumers which in the end is to satisfy consumers(Waluyo, et. al., 2018). Goats are one of the animals that are in great demand by the public for religious ceremonies or consumption, the demand for goats increases at the time of Eid al-Adha for qurban purposes. To get goats, buyers look at the animal market which is only open 2 times a week. There are operational costs and brokers

\section{Research Methods}

The method that we will apply is the face-to-face or direct method by providing training and using presentation slides, application modules and direct practice in using the information system. At the beginning of the meeting, the admins and existing cattle breeders will be given hands-on practice on the level of understanding of the Cattle Sales Information System (SIPEPI). 
Admin and cattle breeders will directly try the use and manage the system that has been running. There are two applications that will provide training to cattle farmers. The first is a web-based application, this application is for managing cow data, buyer data, sales data and reports, while the second is an android-based application to display images and prices of cattle on the Android front page so that buyers are free to choose cattle that have been inputted by cattle farmers. The method of evaluating the achievement of targets is carried out at the beginning and end of the activity. This is to determine the level of knowledge of participants and receive input for improvement in subsequent activities.

\section{Results and Discussions}

System Analysis

System analysis is done by identifying and evaluating the problems that occur, as well as what obstacles exist so that the system can be planned. This system analysis also aims to design and improve existing systems from manual to automatic.

System Design

This stage is the stage after the system analysis is complete, so it can be continued by building an Android-based cattle sales application.

Purpose of System Design

The purpose of the design is to build a system that will be more measurable and consistent so that the objectives of the research will be met.

Overview of the proposed system

Nowadays, the internet is a phenomenal thing and has become a primary thing in life. From the business side, the internet has become a necessity in marketing a product and has even become the most powerful promotional tool because of the speed of its spread. Likewise, making the application for selling cows is expected to be a promotional tool in marketing cows from breeders in the district. Tassel. The system will be made with several levels of access, namely admin, reseller/supplier and consumer levels. Each level has different rights. Orders made by consumers will be processed by the admin by contacting the reseller to prepare the order whether it is available or not. When consumers want to order beef, consumers must register first.

Table 1 - Software Architecture

\begin{tabular}{|c|c|c|}
\hline Category User & Assignment & Right \\
\hline Main Admin & Manage users and data & $\begin{array}{ll}\text { - } & \text { Create users and delete } \\
& \text { users } \\
\text { - } & \text { View and delete data } \\
\text { - } & \text { Make payment } \\
\text { transactions } & \\
\text { - } & \text { Report }\end{array}$ \\
\hline Reseller & As a seller and supplier & $\begin{array}{ll}\text { - } & \text { Input cow data and } \\
\text { prices } \\
\text { - } \\
\text { Delivery of cattle on } \\
\text { request } \\
\text { - } \\
\text { Report }\end{array}$ \\
\hline Consumen & Make orders and purchases & $\begin{array}{ll}\text { - } & \text { Make a payment } \\
\text { - } & \text { Receive orders }\end{array}$ \\
\hline
\end{tabular}

E. Proposed Use Case 


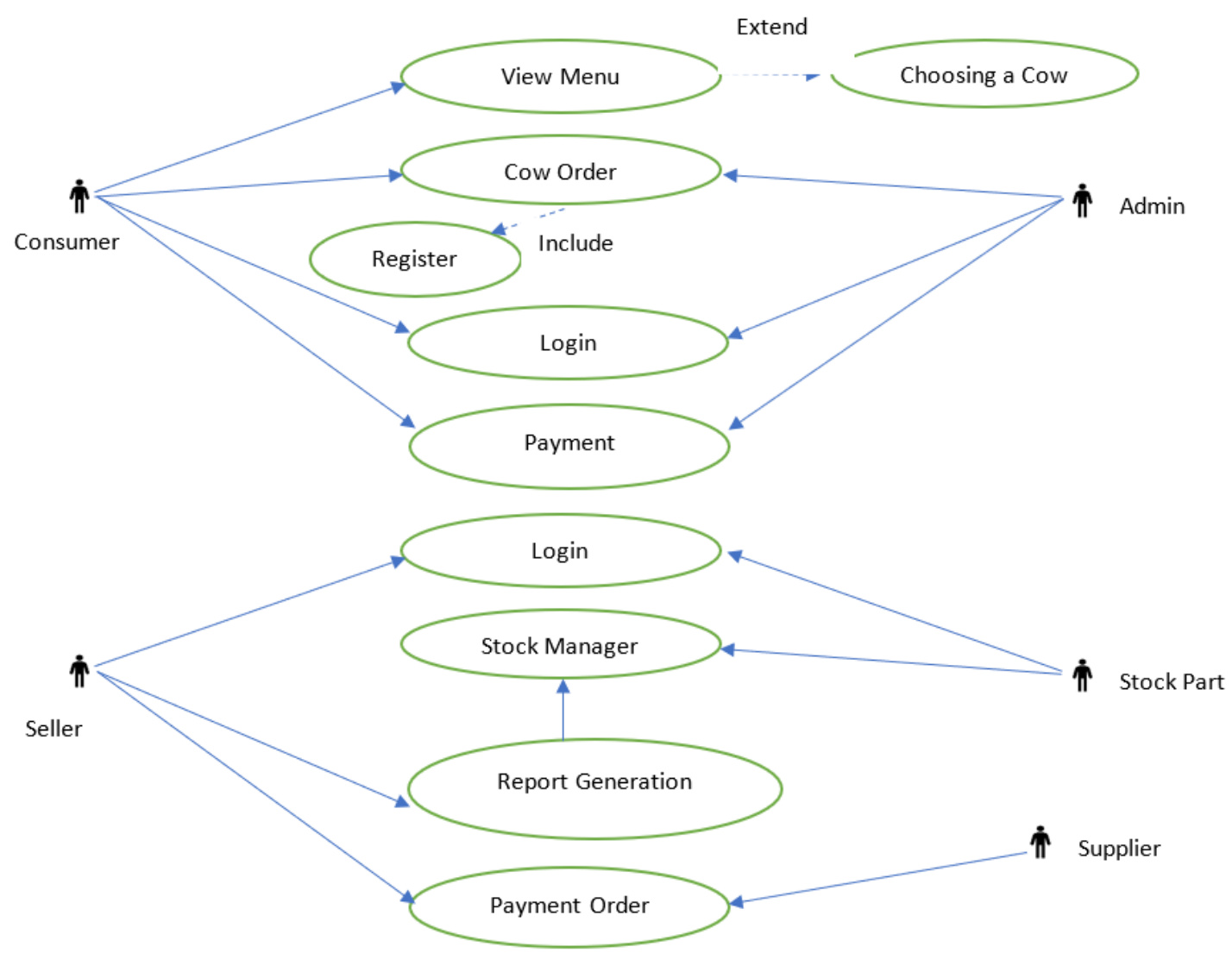

Fig. 1. Proposed Use Case

\section{F. Activity Diagrams}

The following is an Activity Diagram modeling for an Android-Based Cattle Sales Application:

1) Actors install android-based applications

2) After installation, the SIPEPI icon will appear on the smartphone

3) Actors just click the SIPEPI icon, the page will immediately appear

4) The application will display a database query in accordance with the information data desired by the actor.

5) Actors will see Android Based Cattle Sales Application.

6) Process ends

H. System Implementation

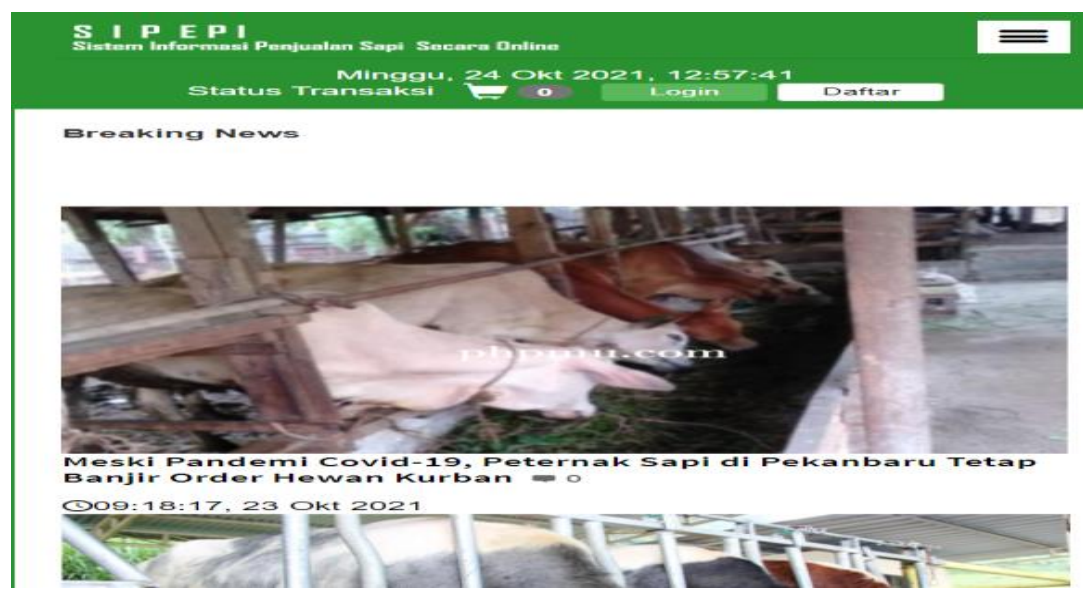

Fig.2. Front page 
SAPI

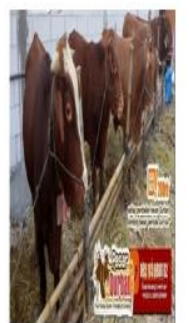

Sapi Pasar2 2

Rp 25,000,000

Stok 3etor

Pelaraboru

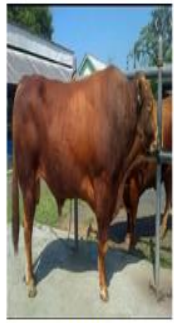

Sapi Qurban2

Rp 100,000,000

Stok 5 ekor

Pelararonu

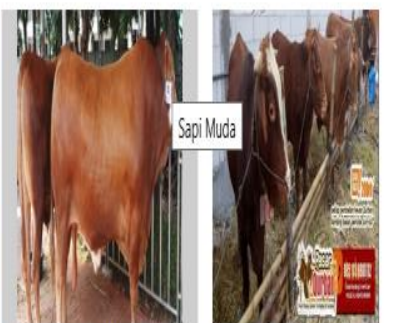

Sapi Muda

Rp $15,000,000$

Stok 5elor

Pelerbaru

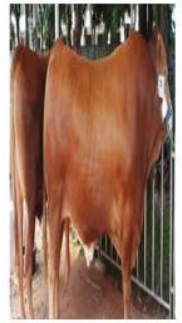

Rp 1,600,000

Stok 20 ekor

Pelarabaru
Sapi Pasar

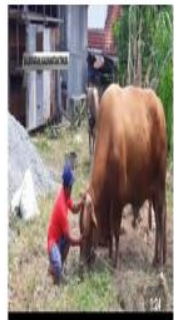

SapiQurban

Rp $16,000,000$

Stok 15 ekor

Pekaraboru
Rp 18,000,000

Siok 10 etor

Pekanbaru

Fig. 3. Cow's Selection Page

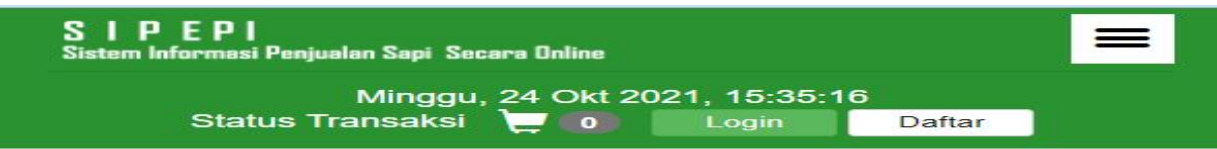

Breaking News

Meski Pandemi Covid-19, Peternak Sapi di Pekanbaru Tetap Banjir Tekan Risiko Kerugian, Peternak di Pekanbaru Asuransikan Ternak

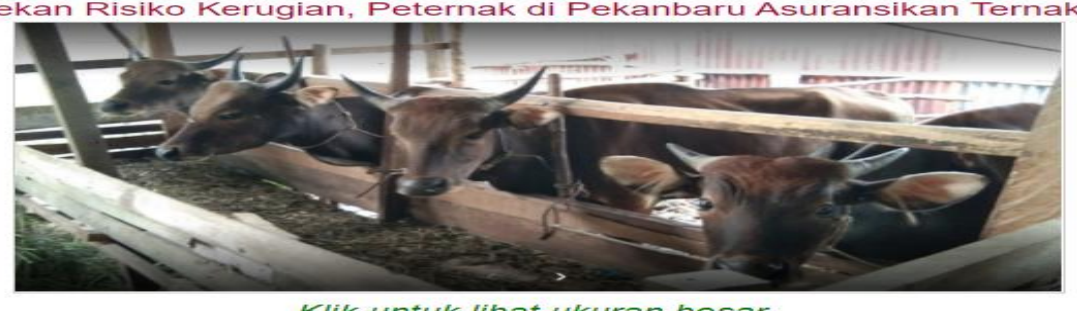

Sapi Kurban Usaha Mandiri

Rp 12,000,000/Ekor

\begin{tabular}{|l|l}
\hline Berat & 120000 Gram \\
\hline Kategori & Sapi \\
\hline Tersedia & 15 stok barang \\
\hline Jumlah Beli & 1 \\
\hline
\end{tabular}

Jaminan 100\% Aman

Uang pasti kembali. Sistem pembayaran bebas

Fig. 4. Consumer Page Chooses Cow 


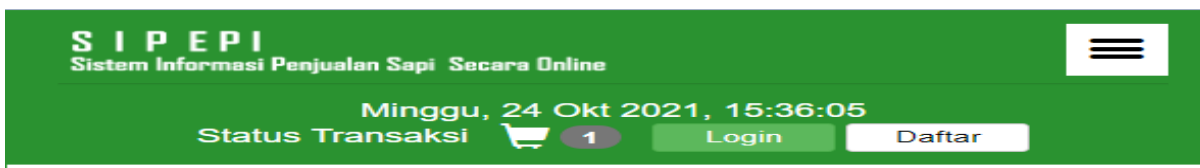

Breaking News

ərnak di Pekanbaru Asuransikan Ternak

BERIKUT DATA PESANAN ANDA

\begin{tabular}{|c|c|c|}
\hline 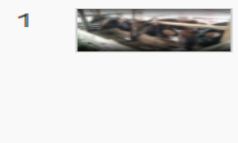 & $\begin{array}{l}\text { Sapi Kurban Usaha } \\
\text { Mandiri } \\
\text { Qty. 1, Harga. Rp } \\
\text { 12,000, OOO / Ekor, } \\
\text { Berat. 120000 Gram }\end{array}$ & $\begin{array}{l}\mathrm{Rp} \\
12,000,000\end{array}$ \\
\hline Total Harga & & $\mathbf{R p} O$ \\
\hline Total Berat & & $\begin{array}{l}120000 \\
\text { Gram }\end{array}$ \\
\hline Lanjut Belanja & Selesai Belanja & \\
\hline Pengirim & Usaha Mandiri & \\
\hline Email & uvdona@gmail.com & \\
\hline Alamat & $\begin{array}{l}\text { Alamat: Jl. Barito Sari } \\
\text { Kec. Rumbai, Kota Pek: } \\
\text { Pekanbaru, Riau }\end{array}$ & $\begin{array}{l}\text { 23, Umban Sari, } \\
\text { ibaru, Riau , }\end{array}$ \\
\hline
\end{tabular}

Fig. 5. The Consumer Page Saves The Message

S I P E P I Penjuan Sapi Serara Dnline
Sistem Informasi Pinggu, 24 Okt $2021,21: 06: 58$

Fig. 6. Customer Page Successfully Logged In 


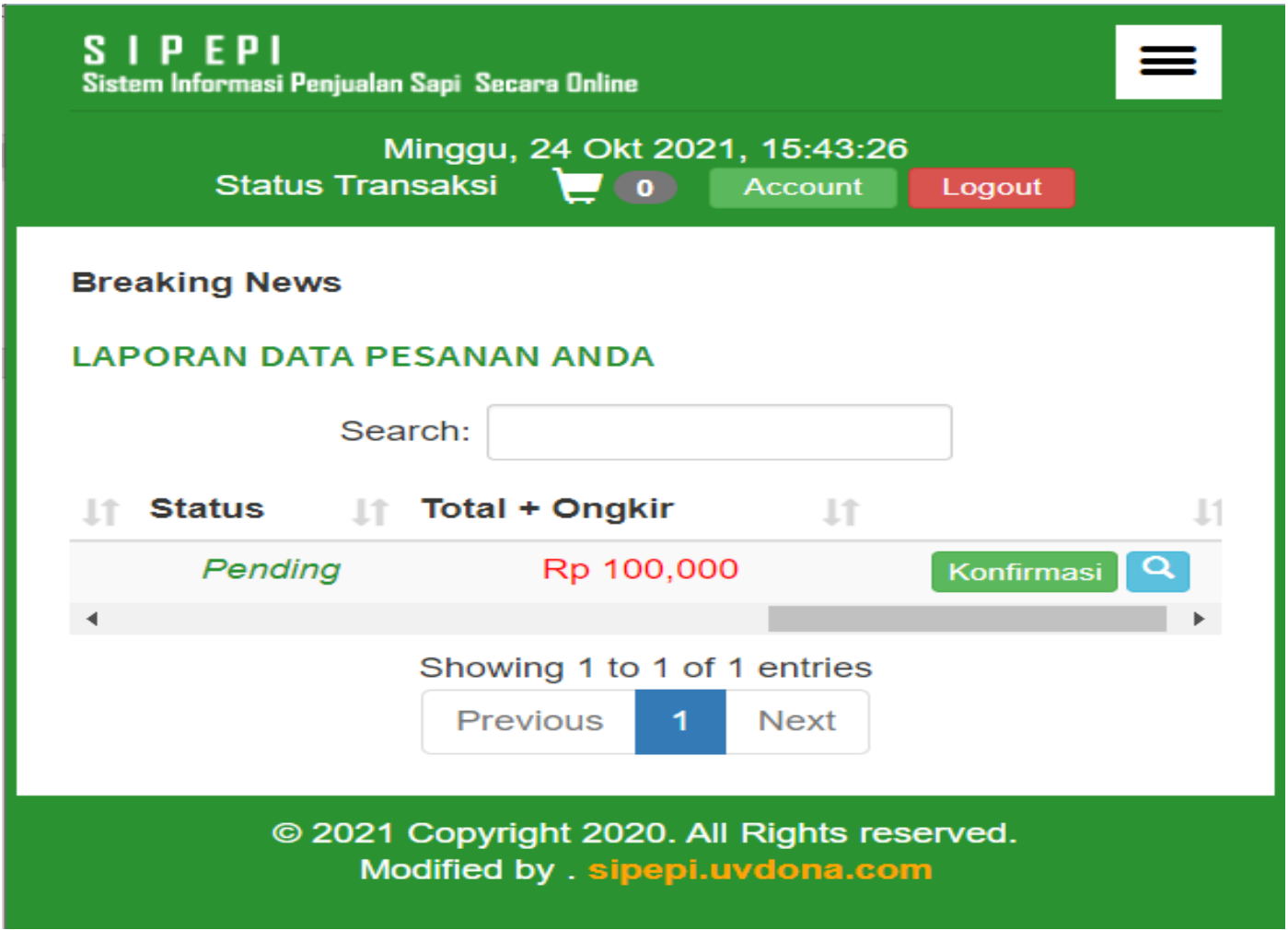

Fig. 7. Order Verification Page

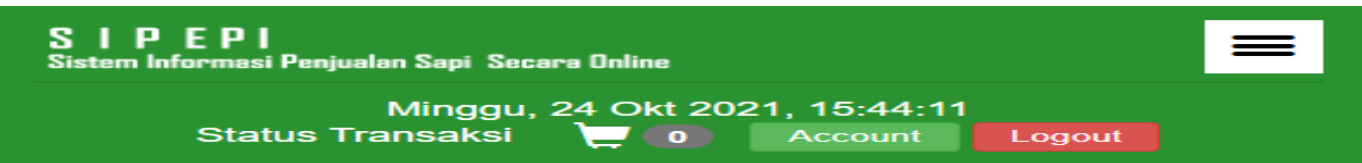

Breaking News

Meski Pandemi Covid-19, Peternak Sapi di Pekanbaru Tetap Banjir ،

Masukkan No Invoice atau No Transaksi Terlebih dahulu!

\begin{tabular}{l|l|}
\hline No Invoice & TRX-20211024154210 \\
\hline Total & Rp 100,000 \\
\hline Transfer Ke \\
\hline Nama Pengirim \\
\hline Tanggal Transfer \\
\hline
\end{tabular}

Fig. 8. Payment Confirmation Page 


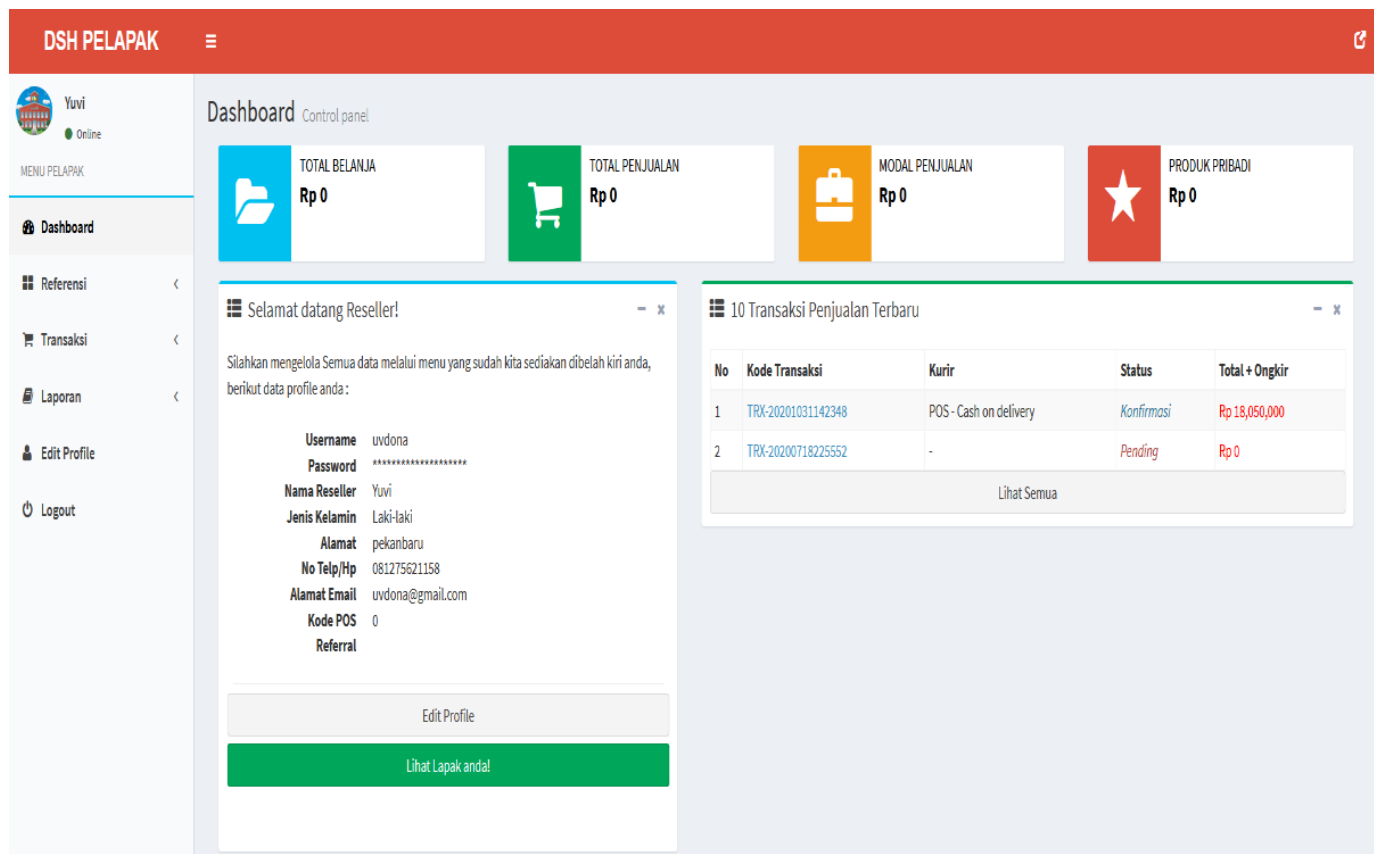

Fig. 9. Reseller Login Page

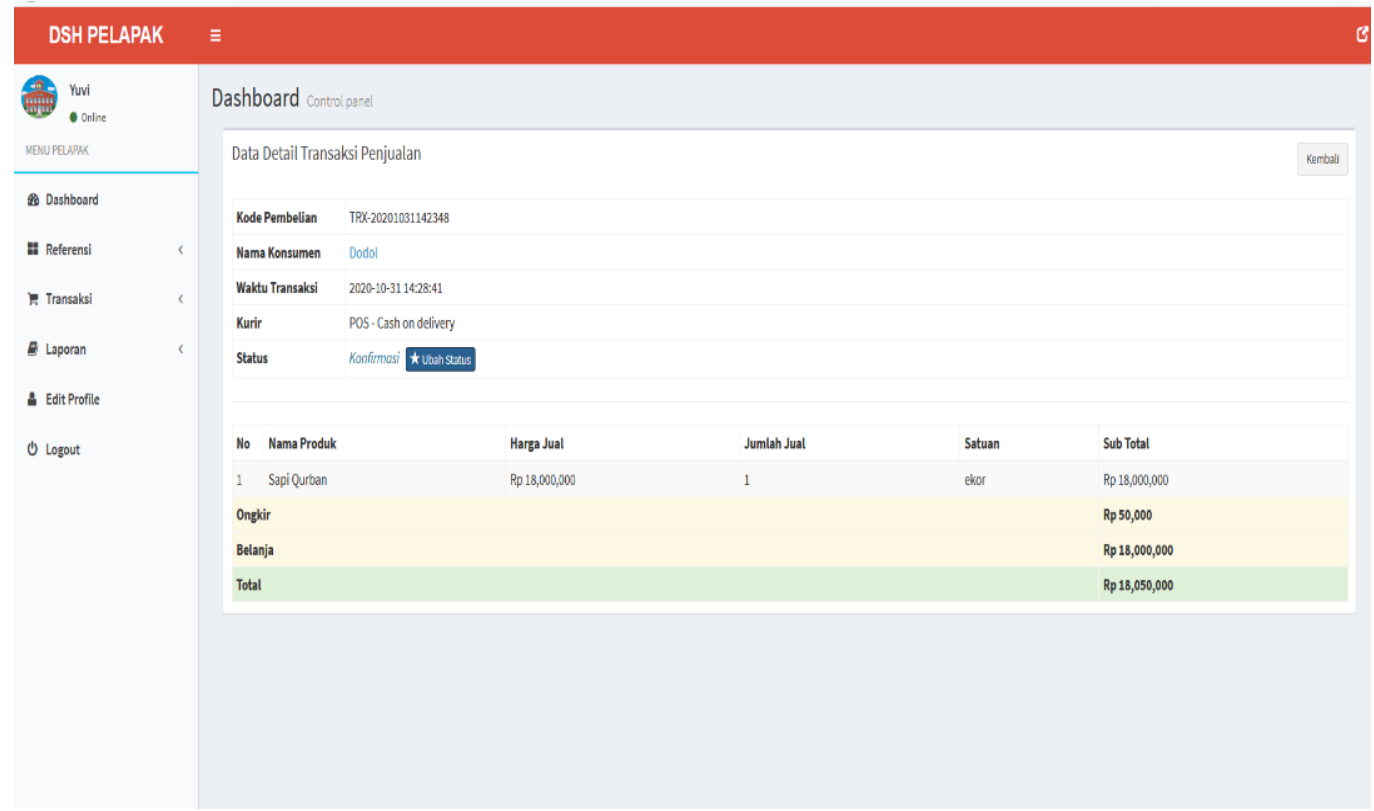

Fig. 10. Payment Confirmation Page By Reseller 


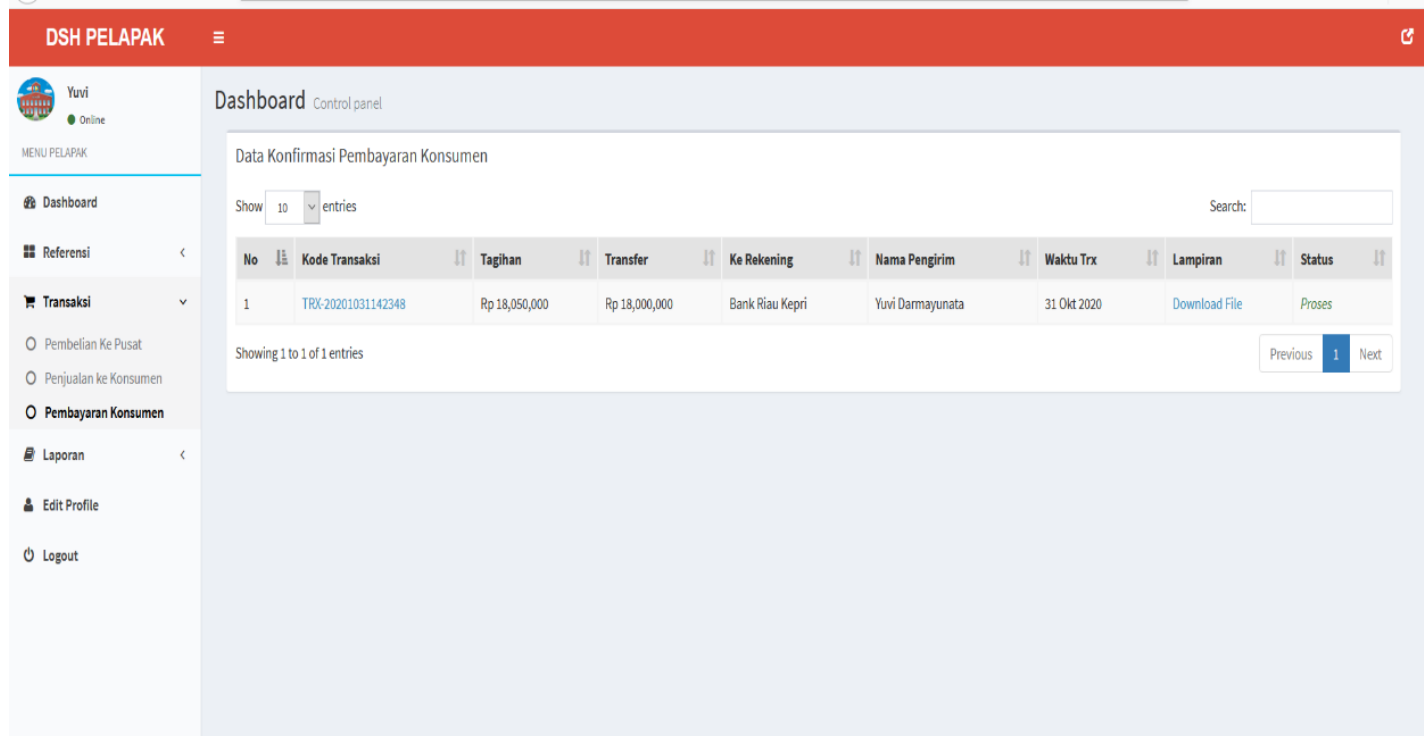

Fig. 11. Proof of Payment Page By Consumers

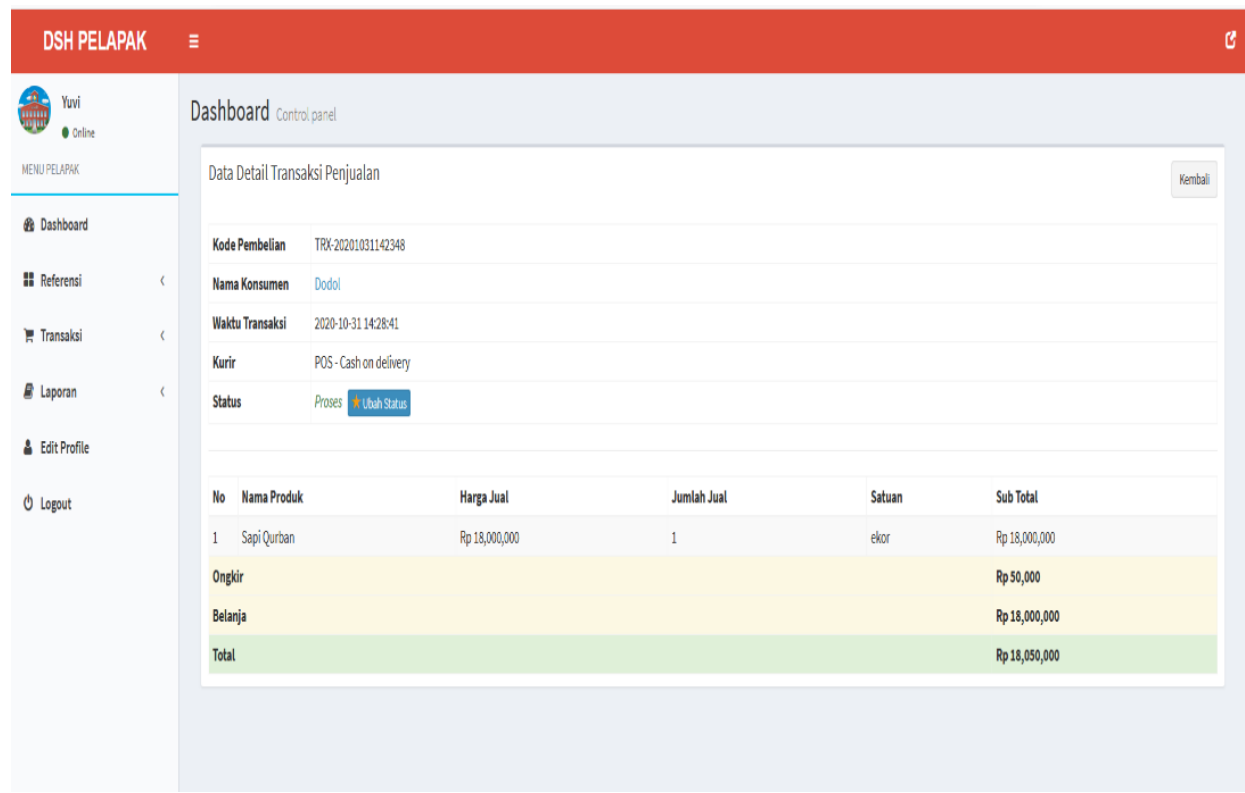

Fig. 12. Transaction Details

\section{Discussions}

In developing this android-based application, the research uses the web view method so that the application is exactly the same as the web-based application. In the current study, researchers will discuss the use of android-based applications by creating an instrument that contains questions about the use of android-based applications. 
Table 2. Recapitulation of Android-Based Application Questionnaire Results Against Sellers

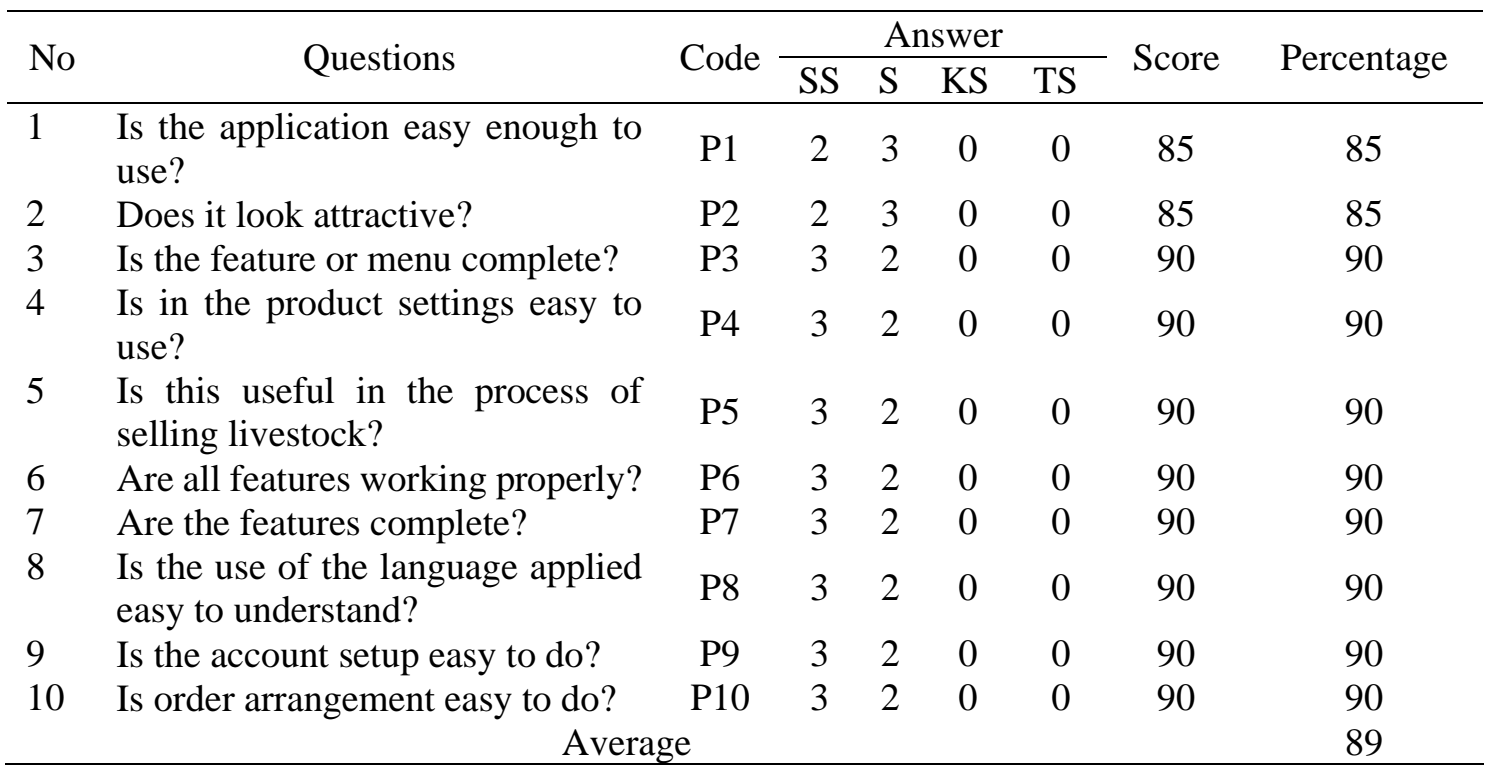

Based on the results of the questionnaire recapitulation from the seller, it can be concluded that the value of $89 \%$ is in the category of strongly agree. This shows that the androidbased application is useful for sellers to market their cattle globally.

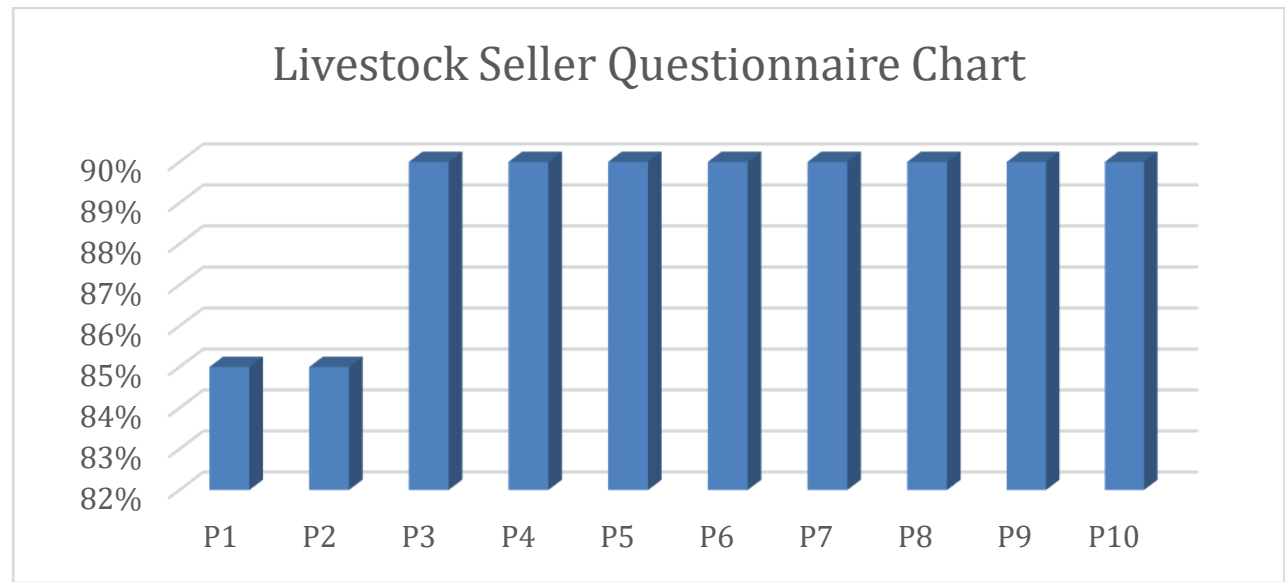

Fig. 13. Consumer Questionnaire Graph as a Seller

Analysis of several respondents from online sellers can be concluded that online sellers state that there are no obstacles in using livestock sales applications, the appearance of the application looks attractive, online sellers know that livestock selling products only accept healthy and worthy livestock, if there are those who sell livestock that are less appropriate, it will be immediately contacted and informed by the livestock sales party then delete it from the livestock application. In addition, the menus in the livestock application do not make it difficult for online sellers, it feels easy and easy to use the livestock sales application(Bruce, et. al., 2021).

Table 3 - Recapitulation of Android-Based Application Questionnaire Results Against Buyer

\begin{tabular}{|c|c|c|c|c|c|c|c|c|}
\hline \multirow{2}{*}{ No } & \multirow{2}{*}{ Questions } & \multirow{2}{*}{ Code } & \multicolumn{4}{|c|}{ Answer } & \multirow{2}{*}{ Score } & \multirow{2}{*}{ Percentage } \\
\hline & & & SS & $\mathrm{S}$ & KS & TS & & \\
\hline 1 & $\begin{array}{l}\text { Is the application easy enough to } \\
\text { use? }\end{array}$ & P1 & 10 & 12 & 0 & 0 & 76 & 76 \\
\hline 2 & Does it look attractive? & $\mathrm{P} 2$ & 7 & 15 & 0 & 0 & 73 & 73 \\
\hline 3 & Is the feature or menu complete? & P3 & 8 & 12 & 0 & 0 & 72 & 72 \\
\hline
\end{tabular}


4 Is in the product settings easy to use?

5 Is this useful in the process of selling livestock?

$\begin{array}{lllllll}\mathrm{P} 4 & 6 & 16 & 0 & 0 & 72 & 72\end{array}$

$\begin{array}{lllllll}\text { P5 } & 10 & 10 & 0 & 0 & 74 & 74\end{array}$

$\begin{array}{lllllllll}\text { Are all features working } & \text { P6 } & 6 & 16 & 0 & 0 & 72 & 72\end{array}$

properly?

7 Are the features complete?

8 Is the use of the language applied easy to understand?

$\begin{array}{lllllllll}9 & \text { Is the account setup easy to do? } & \text { P9 } & 8 & 12 & 0 & 0 & 72 & 72\end{array}$

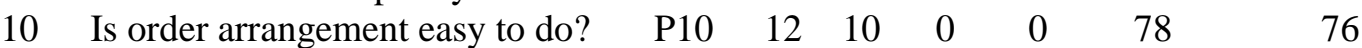

Average

72
74
72
72
75
72
76
3.6

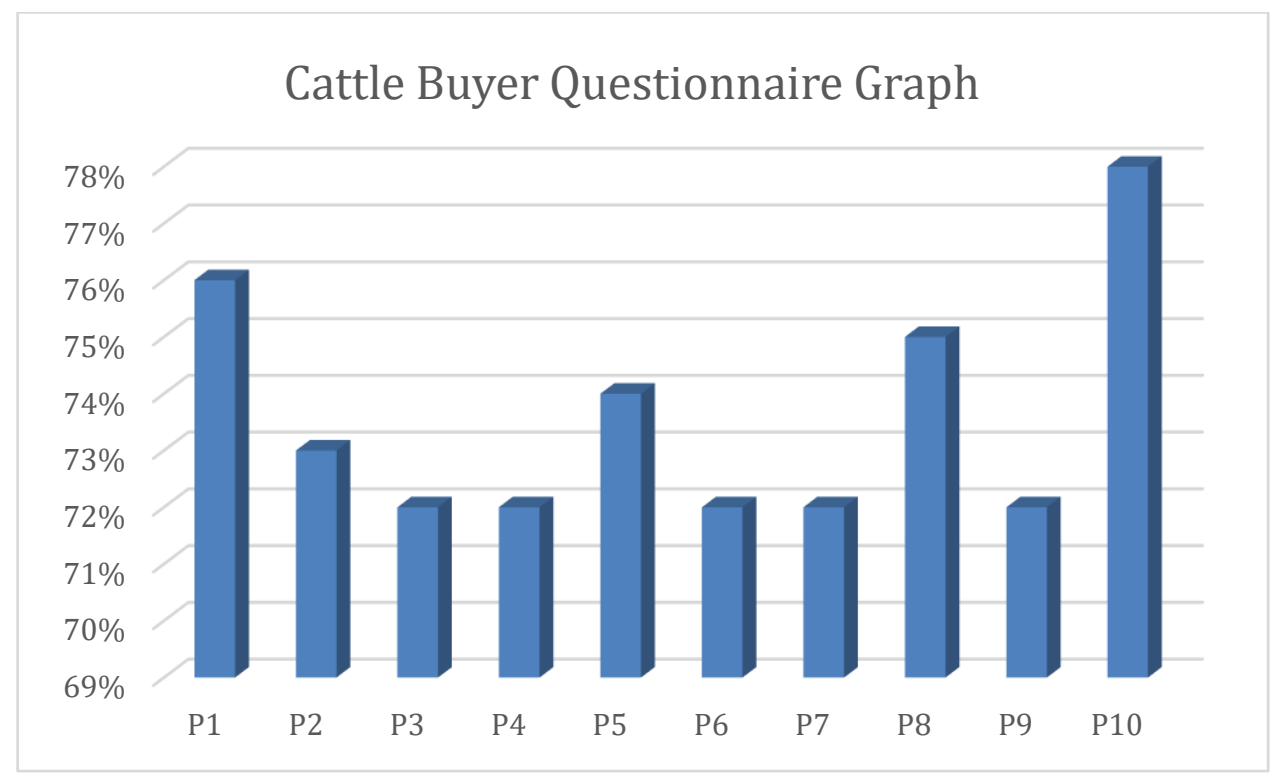

Fig. 14. Consumer Questionnaire Graph as a Buyer

Analysis of the questionnaire to consumers that the design of an Android-based cattle marketing information system is easy to use by consumers because consumers strongly agree with the design of this information system by looking at the average value of $73.6 \%$. In this regard, the rapid development of technology cannot be denied and avoided so that more and more people are interested in buying products online. In addition, this application helps and makes it easier for people to buy and choose livestock as desired. People do not have to be present at the livestock market to get the livestock they need. The existence of the livestock sales application is a new alternative for the community, besides that the livestock sales application is felt by the community to be more effective and efficient because people can directly choose livestock products via Android as needed without having to come to the livestock market and in terms of time buyers also save time because they are special. Buyers who have busy activities and busy schedules can directly order and buy in the livestock sales application.

\section{Conclusion}

The conclusions obtained by the researchers, after conducting this research are: Researchers have succeeded in making an android application prototype. This android application can help cattle sellers to sell livestock products to consumers so that they can increase their livestock sales. This application can help consumers find cattle and can compare prices between fellow cattle sellers. This application can facilitate transactions between sellers and consumers so that they can avoid fraud in transactions. From the results of the questionnaire, sellers and consumers agree with this android-based application. With the many benefits that can be obtained, 
of course the application must be developed more optimally, especially in terms of server infrastructure, because there will be many who access the Android-based application. Continue to improve the security of the application so that consumers feel more comfortable in using it. It is hoped that in the future it will not only sell cattle, but also sell other livestock such as goats, chickens, ducks and others.

\section{References}

Afandi, M. F., Khusaini, M. A., Nuphanudin, N., Purwanto, H., \& Prakoso, K. A. (2021, March). TernAkses: Livestock investment based on crowdfunding through custodial services and millennial farms planning. In IOP Conference Series: Materials Science and Engineering (Vol. 1098, No. 5, p. 052073). IOP Publishing.

Aprilia, L., Cyrilla, L., \& Burhanuddin, B. (2018). Analisis Strategi Pemasaran Ternak Berbasis E-Commerce di PT X. Jurnal Ilmu Produksi dan Teknologi Hasil Peternakan, 6(3), 121129.

Gupta, P. J., Mhatre, H. R., Chaudhari, A. P., \& Pathari, R. (2018, January). Smart Livestock Trading. In 2018 International Conference on Smart City and Emerging Technology (ICSCET) (pp. 1-7). IEEE.

Hao, J., Bijman, J., Gardebroek, C., Heerink, N., Heijman, W., \& Huo, X. (2018). Cooperative membership and farmers' choice of marketing channels-Evidence from apple farmers in Shaanxi and Shandong Provinces, China. Food Policy, 74, 53-64.

Jamal, E. (2016, September). Analisis pemasaran sapi potong di Propinsi Bali. In Forum penelitian Agro Ekonomi (Vol. 12, No. 1, pp. 30-37).

Kango, U., Astuti, W., \& Firdiansjah, A. (2020). Analysis of the Description of Experiential Marketing, Store Atmosphere and Local Retail Customer Satisfaction of Gorontalo City, Indonesia. International Journal of Advances in Scientific Research and Engineering (IJASRE), 6(12), 159-167.

Karray, S., Martín-Herrán, G., \& Sigué, S. P. (2021). Managing advertising investments in marketing channels. Journal of Retailing and Consumer Services, 102852.

Khuluqil Rahmat Hidayat, K. R. H. (2019). Perancangan Aplikasi Penjualan Ternak Berbasis Android (Studi Kasus Pada Kelompok Ternak Wonosari Desa Warugunung Kecamatan Pacet Mojokerto) (Doctoral Dissertation, Universitas Islam Majapahit Mojokerto).

Kitano, S., Mitsunari, Y., \& Yoshino, A. (2022). The impact of information asymmetry on animal welfare-friendly consumption: Evidence from milk market in Japan. Ecological Economics, 191, 107230.

Kotler, P., Kartajaya, H., \& Setiawan, I. (2021). Marketing 5.0: Technology for humanity. John Wiley \& Sons.

Lole, U. R., Keban, A., Sogen, J. G., \& Mulyantini, N. G. A. (2021). Supply and Value Chain Models in Cattle Marketing and Its Derivative Products in East Nusa Tenggara Province. Animal Production, 197-208.

Ostaev, G. Y., Gogolev, I. M., Kondratiev, D. V., Markovina, E. V., Mironova, M. V., Kravchenko, N. A., \& Aleksandrova, E. V. (2019). Strategic budgeting in the accounting and management system of agricultural enterprises. Indo American Journal of Pharmaceutical Sciences, 6(4), 8180-8186.

Pabbo, B. (2016). Analisis Margin Pemasaran Sapi Bali Pada Kelompok Tani Ramah Lingkungan Di Desa Galung Kecamatan Barru Kabupaten Barru. Jurnal Galung Tropika, 5(2), 130142.

Pakaya, R., Tapate, A. R., \& Suleman, S. (2020). Perancangan Aplikasi Penjualan Hewan Ternak Untuk Qurban Dan Aqiqah Dengan Metode Unified Modeling Language (UML). Jurnal Technopreneur (Jtech), 8(1), 31-40.

Printezis, I., \& Grebitus, C. (2018). Marketing channels for local food. ecological economics, 152, 161-171.

Purba, H. J., \& Hadi, P. U. (2012). Dinamika dan kebijakan pemasaran produk ternak sapi potong di Indonesia Timur.

Rasda, M., Ali, M. S. S., Naping, H., \& Busthanul, N. (2021). Mattirowalie Traditional Market Structure in Barru Regency. Advances in Environmental Biology, 15(2), 1-6. 
Rohmawati, T., \& Ramadhani, F. (2020, July). Android Based Livestock Sales Application Information System. In IOP Conference Series: Materials Science and Engineering (Vol. 879, No. 1, p. 012005). IOP Publishing.

Saravanan, K., \& Saraniya, S. (2018). Cloud IOT based novel livestock monitoring and identification system using UID. Sensor Review.

Sharma, H., \& Burark, S. S. (2019). Agricultural Marketing in Rajasthan: Status, Problems and Remedies. Emerging Issues in Agribusiness Management in India, 197.

Subagyo, U., \& Ardiansyah, D. (2020, July). Prototype of Integrated Livestock Recording Application with Animal Identification and Certification System in Kebumen. In Journal of Physics: Conference Series (Vol. 1577, No. 1, p. 012053). IOP Publishing.

Susilowati, M., \& Wahid, H. N. (2018). Perancangan Marketplace Investasi Peternakan Online Pada Startup Farmerid. SMARTICS Journal, 4(1), 11-17.

Waluyo, R., Karini, Z., \& Purnomo, K. A. (2018). Aplikasi M-Commerce Berbasis Android Sebagai Media Informasi dan Penjualan Kambing. Jurnal CoreIT: Jurnal Hasil Penelitian Ilmu Komputer dan Teknologi Informasi, 4(1), 1-7.

Zhang, P., Yin, G., \& Duan, M. (2020). Distortion effects of emissions trading system on intrasector competition and carbon leakage: A case study of China. Energy Policy, 137, 111126. 